\title{
Growth, nutrient concentration, nutrient accumulation and visual symptoms of nutrient deficiencies in cherry tomato plants ${ }^{1}$
}

\section{Crescimento, teor, acúmulo e sintomas visuais de deficiência de nutrientes em plantas de tomateiro do grupo cereja}

\author{
Janini Tatiane Lima Souza Maia²; Hermínia Emília Prieto Martinez³ Junia Maria \\ Clemente $^{4}$; Marilia Contin Ventrella ${ }^{5}$; Carla do Carmo Milagres ${ }^{4 *}$
}

\begin{abstract}
Tomato is one of the most popular vegetables, with high nutrient demand. The nutrient concentration can vary depending on the development phase, cultivation system, temperature, soil conditions, luminosity, relative humidity and management practices. The aim of this work was to characterize cherry tomato visual symptoms of deficiency, as well as the effect of nutritional restriction on the development and nutrient concentration of plants cultivated in nutrient solution. Plants of the cherry tomato, cultivar Sindy, were grown in green house. We have used eleven treatments, one control with complete nutrient solution and the other ten omitting respectively the nutrients nitrogen, phosphorus, potassium, calcium, magnesium, sulfur, boron, copper, zinc and iron. The experiment was performed in randomized design with three repetitions. After 60 days, the plants were removed from the solutions and their main symptoms were photographed and described. The traits evaluated were: total dry matter yield, dry matter of leaves, dry matter of stems and dry matter of roots; number of leaves, number of inflorescences; number of fruits and root volume. The concentration and accumulation of nutrients: nitrogen, phosphorus, potassium, calcium, magnesium, sulfur, boron, copper, zinc and iron in leaves, stems and roots were evaluated. Nutrient concentration and accumulation were influenced by the deficiencies imposed. The visual symptoms of deficiency that had appeared firstly were those of phosphorus, boron and iron, respectively. The omissions of the nutrients nitrogen, magnesium and boron were the ones that most compromised the dry matter production of the cherry tomato plants.
\end{abstract}

Key words: Missing nutrient. Solanum lycopersicum L. Nutrient solution.

\section{Resumo}

O tomate é uma das hortaliças mais populares e uma das mais exigentes em nutrientes, e conforme a etapa de desenvolvimento, cultivar, temperatura, solo, luminosidade, umidade relativa e manejo adotado, os teores médios de nutrientes podem variar. Dessa forma objetivou-se com este trabalho caracterizar, em solução nutritiva, os sintomas visuais de deficiência, bem como o efeito da restrição nutricional no desenvolvimento e nos teores de nutrientes em plantas de tomateiro do tipo cereja cv. Sindy. As plantas foram conduzidas em solução nutritiva, em casa de vegetação. Empregaram-se 11

1 Parte da Tese de Doutorado do primeiro autor.

2 Prof ${ }^{a}$, Universidade Federal de Minas Gerais, UFMG, Instituto de Ciências Agrárias, Montes Claros, MG, Brasil. E-mail: janinitatimaia@yahoo.com.br

3 Prof ${ }^{a}$, Universidade Federal de Viçosa, UFV, Departamento de Fitotecnia, Viçosa, MG, Brasil. E-mail: hermina@ufv.br

4 Pós-Doutoranda, UFV, Departamento de Fitotecnia, Viçosa, MG, Brasil. E-mail: junia.clemente@yahoo.com.br; carlacmilagres@ yahoo.com.br

5 Prof ${ }^{a}$, Universidade Federal de Viçosa, UFV, Departamento de Botânica, Viçosa, MG, Brasil. E-mail: ventrella@ufv.br

Author for correspondence 
tratamentos, um controle com solução nutritiva completa e os demais omitindo-se respectivamente os nutrientes: nitrogênio, fósforo, potássio, cálcio, magnésio, enxofre, boro, cobre, zinco e ferro. $\mathrm{O}$ delineamento experimental utilizado foi o inteiramente casualizado, com três repetições. Após 60 dias, as plantas foram retiradas das soluções, sendo seus principais sintomas fotografados e descritos. As variáveis avaliadas foram: produção de matéria seca total, de folhas, caules e raízes; número de folhas, inflorescências e frutos e volume radicular. Também foram avaliados o teor e o acúmulo dos nutrientes: nitrogênio, fósforo, potássio, cálcio, magnésio, enxofre, boro, cobre, zinco e ferro nas folhas, caules e raízes. Os teores e acúmulos dos nutrientes foram influenciados pelas deficiências impostas. Os sintomas visuais de carência que primeiro se manifestaram foram os de fósforo, boro e ferro, respectivamente. As omissões dos nutrientes nitrogênio, magnésio e boro foram as que mais comprometeram a produção de matéria seca das plantas de tomateiro cereja.

Palavras-chave: Elemento faltante. Solanum lycopersicum L. Solução nutritiva.

\section{Introduction}

The tomato fruit has high nutritional value. It can be highlighted its functional properties and the presence of antioxidants, besides being a source of vitamins and lycopene. Tomato crop has high commercial value and fast economic return, mainly for cherry tomatoes. The market for cherry tomato has been growing in recent years due to its appearance, smaller size, appreciated flavor, high soluble solids content ( ${ }^{\circ}$ Brix), and because its fruits are a good option for dishes decoration (CARVALHO; PAGLIUCA, 2007; SILVA et al., 2011a).

As in other vegetable crops, for tomato it is established that fruit quality as well as productivity are influenced by adequate mineral nutrition (SASAKI; SENO, 1994), since the deficiency or the excess of nutrients compromises the metabolism of the plants (ALVARENGA, 2013).

The mineral nutrition of cultivated plants are of extreme importance, since it affects the production. Besides, the cost to produce is higher when plants undergo nutritional stress (CAMBRAIA, 2005), and although the mechanisms with which the plants react to the nutritional stresses are similar, small peculiarities are observed between species and/or cultivars.

The lack of an essential element for plant growth and development triggers biochemical responses, which are manifested by typical symptoms
(EPSTEIN; BLOOM, 2006). One of the practical ways of detecting the limiting element to growth, besides leaf diagnosis, is through the visual aspect of plants. It is known that mineral deficiencies promote changes in metabolism, which often modify morphological and anatomical leaf aspects (SILVEIRA et al., 2002).

The nutritional status of plants can be evaluated through visual diagnosis (observation of the symptoms of deficiency or excess of nutrients), which is of great importance because it allows quick decisions to correct nutritional imbalances. This diagnosis consists of characterizing, describing and/or photographing, at the earliest and the most detailed possible, the deficiency/excess symptoms in the problem plant and comparing them with the standard deficiency/excess symptoms of each nutrient described in the literature (FONTES, 2001).

In the recent years, several studies have been carried out on cherry tomato, some of which are related to production (TRANI et al., 2003; GOMES et al., 2011; SANTOS et al., 2016), tolerance to water stress (SÁNCHEZ-RODRÍGUEZ et., 2011, 2012, 2014) and saline stress (HAGHIGHI; PESSARAKLI, 2013), while others are related to their morphology (RODRIGUES et al., 2012; ROCHA, 2009). It is observed that few among them are related to plant nutrition (FELTRIN et al., 2005; GENUNCIO et al., 2010; ABRAHÃO et al., 2011; SHABANI et al., 2012), and those describing 
their visual symptoms of macro and micronutrient deficiencies are scarce.

In view of the described above, this work was conducted with the objective of characterizing the visual symptoms of deficiency, as well as the effect of nutritional restriction on development and nutrient concentration of cherry tomato plants growing in nutrient solution.

\section{Material and Methods}

The experiment was conducted in a greenhouse of the Plant Mineral Nutrition Laboratory of the Plant Science Department of the Universidade Federal de Viçosa (UFV), Viçosa, MG, Brazil. We have essayed the cherry group, hybrid cultivar Sindy, The seedlings were produced in trays containing commercial substrate, based on Pinus bark without addition of nutritive solution. After the plants presented two definitive leaves, they were selected by uniformity, transferred to plastic vessels of $8 \mathrm{~L}$ capacity and submitted to the treatments.

The treatments consisted of the complete nutrient solution, described by Fernandes et al. (2002), or similar solutions in which one element at a time was omitted. The experimental design was completely randomized, with three repetitions, and the treatments were: complete, minus of nitrogen $(\mathrm{N})$, phosphorus $(\mathrm{P})$, potassium $(\mathrm{K})$, calcium $(\mathrm{Ca})$, magnesium $(\mathrm{Mg})$, sulfur $(\mathrm{S})$, boron $(\mathrm{B})$, iron $(\mathrm{Fe})$, zinc $(\mathrm{Zn})$ and copper $(\mathrm{Cu})$, totaling 33 plots.

The complete nutrient solution had the following composition: $\mathrm{N}=8 \mathrm{mmoL}^{-1} ; \mathrm{P}=2 \mathrm{mmoL}^{-1} ; \mathrm{K}=$ $4 \mathrm{mmoL}^{-1} ; \mathrm{Ca}=2 \mathrm{mmoL}^{-1} ; \mathrm{Mg}=1 \mathrm{mmoL}^{-1}$; $\mathrm{S}=1 \mathrm{mmoL}^{-1} ; \mathrm{B}=21 \mu \mathrm{moL}^{-1} ; \mathrm{Cu}=0.9 \mu \mathrm{moL}^{-1}$; $\mathrm{Fe}=35 \mu \mathrm{moL}^{-1}$; manganese $(\mathrm{Mn})=15 \mu \mathrm{moL}^{-1}$; molybdenum $(\mathrm{Mo})=0.7 \mu \mathrm{moL}^{-1} ; \mathrm{Zn}=0.4 \mu \mathrm{moL}^{-}$ 1. To avoid excessive amounts of sodium $\left(\mathrm{Na}^{+}\right)$or chlorine $\left(\mathrm{Cl}^{-}\right)$, due to the omissions of anions and cations, in the treatments without $\mathrm{N}, \mathrm{K}$ and $\mathrm{Ca}$, instead of total omission, it was provided 25, 25 and
$50 \%$ respectively, of the amounts of these nutrients provided by the complete nutrient solution.

The nutrient solution was maintained under constant aeration; the water volume consumed was completed with deionized water; and the $\mathrm{pH}$ was monitored and adjusted to $5.5 \pm 0.5$, with $1 \mathrm{~mol}$ $\mathrm{L}^{-1} \mathrm{HCl}$ or $1 \mathrm{~mol} \mathrm{~L}^{-1} \mathrm{NaOH}$, both once a day. The solution exchange was performed whenever the initial electrical conductivity had a reduction of $30 \%$.

After 60 days, the plants were removed from the solutions and their main symptoms were photographed and described. The following traits were evaluated: total (DMT), leaf (DML), stem (DMS) and root (DMR) dry mass; number of leaves (NL), number of inflorescences (NI), number of fruits (NFr); and root volume (RV).

The samples were then milled in a Wiley-type mill equipped with a 20 mesh screen and subsequently a sub-sample was subjected to nitric-perchloric digestion. The $\mathrm{K}$ concentration was determined by flame emission photometry (BLANCHAR et al., 1965); P dosed colorimetrically by the method of reduction of phosphomolybdate by vitamin C (BRAGA; DEFELIPO, 1974); S by sulphate turbidimetry and $\mathrm{Ca}, \mathrm{Mg}, \mathrm{Cu}, \mathrm{Fe}$ and $\mathrm{Zn}$ by atomic absorption spectrophotometry (BLANCHAR et al., 1965). The concentration of B was determined by dry digestion, followed by azomethine-H base dosing using spectrophotometer of molecular absorption (MALAVOLTA et al., 1997). Another sub-sample was submitted to sulfur digestion for $\mathrm{N}$ analysis by the micro-Kjeldahl method (BATAGLIA et al., 1983). The nutrient accumulation was obtained by multiplying the concentration in $\mathrm{g} \mathrm{kg}^{-1}$ or $\mathrm{mg} \mathrm{kg}^{-1}$ by the weight of the dry mass $(\mathrm{kg})$ of each plant part: leaves, stem and roots.

The data were submitted to Analysis of Variance and the means obtained for each treatment were compared to the control treatment (complete solution) by the Dunnett test, at $5 \%$ probability. 


\section{Results and Discussion}

\section{Symptoms of deficiency}

The lack of all nutrient essayed significantly affected the development of cherry tomato plants.
The results concerning the average number of leaves, inflorescences, fruits; root volume and dry matter of leaves, stem, roots and total are presented in Table 1.

Table 1. Number of leaves (NL), inflorescences (NI) and fruit (NFr), root volume (RV) and dry matter production of leaves (DML), stem (DMS), root (DMR) and total (DMT) in cherry tomato plants submitted to nutritional deficiency in hydroponic system.

\begin{tabular}{lcccccccc}
\hline Treatament & NL & NI & NFr & RV $(\mathrm{ml})$ & DML $(\mathrm{g})$ & DMS $(\mathrm{g})$ & DMR $(\mathrm{g})$ & DMT $(\mathrm{g})$ \\
\hline Complete & 13.33 & 16.00 & 8.67 & 53.33 & 10.72 & 7.93 & 2.13 & 21.83 \\
\hline - N & $11.00^{*}$ & $7.00^{*}$ & 8.67 & $20.00^{*}$ & $4.11^{*}$ & $4.06^{*}$ & $0.68^{*}$ & $9.54^{*}$ \\
- P & 14.33 & 12.00 & $4.00^{*}$ & $40.00^{*}$ & $7.43^{*}$ & $4.27^{*}$ & $1.44^{*}$ & $13.51^{*}$ \\
- K & 14.33 & $32.00^{*}$ & $4.33^{*}$ & 58.33 & $8.50^{*}$ & $6.27^{*}$ & 2.28 & $17.65^{*}$ \\
- Ca & 13.00 & 11.67 & 6.33 & $33.33^{*}$ & $8.06^{*}$ & $6.82^{*}$ & 1.52 & $17.23^{*}$ \\
- Mg & 12.33 & $4.33^{*}$ & $5.00^{*}$ & $18.33^{*}$ & $5.41^{*}$ & $3.39^{*}$ & $0.49^{*}$ & $9.88^{*}$ \\
$-\mathrm{S}$ & 12.67 & 11.00 & 5.33 & $28.33^{*}$ & $5.84^{*}$ & $4.40^{*}$ & $1.19^{*}$ & $11.85^{*}$ \\
- B & $6.67^{*}$ & $0.0^{*}$ & $0.0^{*}$ & $5.00^{*}$ & $1.80^{*}$ & $0.55^{*}$ & $0.24^{*}$ & $2.59^{*}$ \\
$-\mathrm{Cu}$ & 14.33 & 20.33 & 7.67 & 47.33 & $8.86^{*}$ & 7.10 & 1.92 & $18.91^{*}$ \\
$-\mathrm{Zn}$ & 14.00 & $24.33^{*}$ & 7.67 & $36.67^{*}$ & 10.06 & 8.31 & 1.85 & 21.49 \\
$-\mathrm{Fe}$ & 14.33 & 15.00 & $4.00^{*}$ & $36.67^{*}$ & 9.22 & $5.72^{*}$ & 1.56 & $17.35^{*}$ \\
\hline $\mathrm{CV}(\%)$ & 12.87 & 16.03 & 34.82 & 44.78 & 20.08 & 33.42 & 14.68 & 12.12 \\
\hline
\end{tabular}

Means followed by * in the column differ from the complete solution treatment by the Dunnett test at 5\% probability.

\section{Nitrogen}

A $75 \%$ of $\mathrm{N}$ reduction in the nutritive solution compromised the development of the cherry tomato plants, which presented lower values of all the evaluated biometric characteristics, excepting the number of fruits, comparatively to the control treatment. Deficiency symptoms were observed in both, the aerial part (Figure 1B) and the roots (Figure 2B). In the aerial part, the plants presented generalized chlorosis, most intense in older leaves which senesced most quickly when compared to the older leaves of the complete treatment.

The visual symptoms of $\mathrm{N}$ deficiency in cherry tomato were similar to those observed in lulo plants (Solanum quitoense Lam. Var. Quitoense), a species from the Andes, also from the Solanaceae family (BOLÍVAR et al., 2009). These authors still observed a marked reduction in leaf number and leaf area when comparing the treatment with $\mathrm{N}$ restriction to the control treatment. $\mathrm{N}$ is part of the chlorophyll compound, so its lack compromises the chlorophyll content in the plant, which is related to the occurrence of chlorosis, as observed in cherry tomato leaves. $\mathrm{N}$ deficiency severely decreases chlorophyll content, photosynthesis, biomass accumulation and tomato plant growth (KANAI et al., 2008; KHAVARI-NEJAD et al., 2009).

Although leaf and root deficiency symptoms were observed, the $\mathrm{N}$ concentration in these respective organs did not present significant differences compared to the control treatment (Table 2). However, the accumulation of $\mathrm{N}$ in the leaves and stems showed reductions of $80 \%$ and $65 \%$, respectively in relation to the control (Table 3 ), indicating that the concentrations were maintained 
due to growth reduction. The oldest leaves of the cherry tomato were the first to show $\mathrm{N}$ deficiency, since the translocation of this nutrient in the plant is great (ALVARENGA, 2013). In this way, as the plants were deficient in $\mathrm{N}$, they presented a delayed growth, since the $\mathrm{N}$ is the main element of the proteins, that are essential to form tissues, then responsible for plant growth (UCHIDA, 2000). Consequently, the plants also presented petioles and stems with light green coloration and smaller diameter.

Figure 1. Visual symptoms of nutritional deficiencies in the aerial part of cherry tomato cv. Sindy. Complete solution treatment (A), deficiencies: nitrogen (B), phosphorus (C and D), magnesium (E), sulfur (F) and boron ( $\mathrm{G}$ and $\mathrm{H})$.
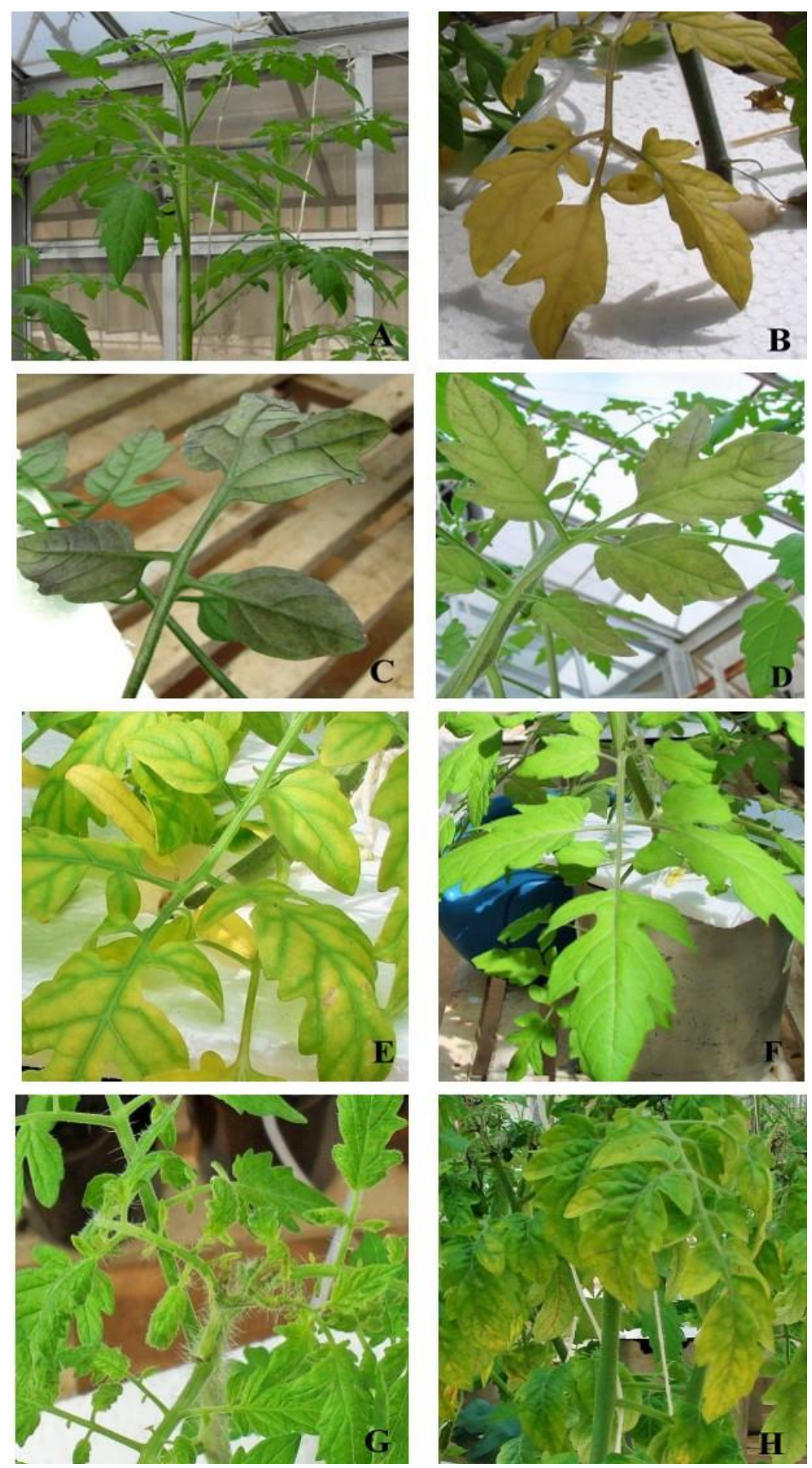
Figure 2. Visual symptoms of nutritional deficiencies in the roots of cherry-type tomato cv. Sindy. Complete solution treatment (A), deficiencies: nitrogen (B), phosphorus (C), calcium (D), magnesium (E), sulfur (F), boron (G), zinc (H) and iron (I).

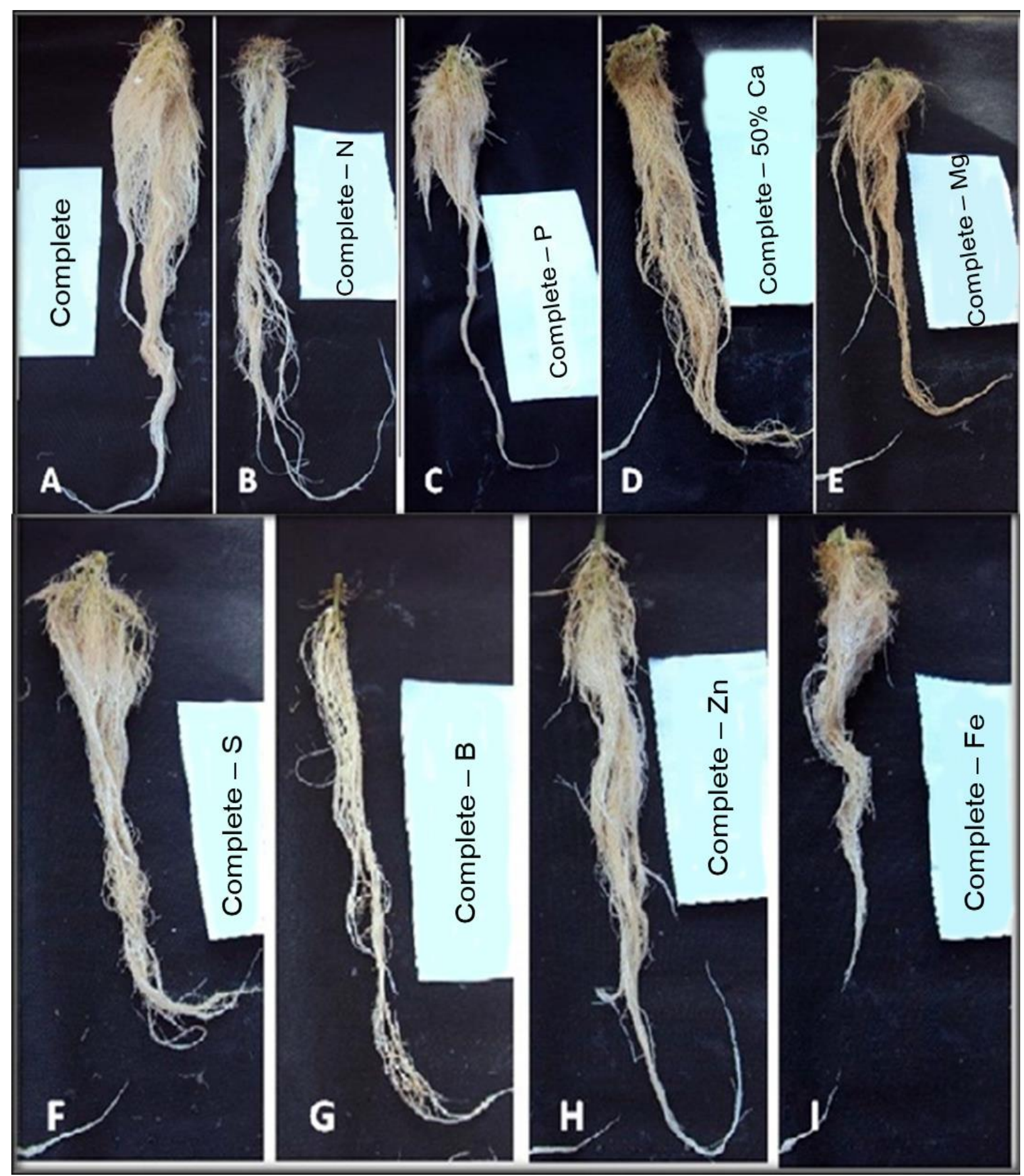


Table 2. Macronutrients $\left(\mathrm{dag} \mathrm{kg}^{-1}\right)$ and micronutrients $\left(\mathrm{mg} \mathrm{kg}^{-1}\right)$ concentration in leaves stem and roots of cherry tomato under nutritional deficiencies in hydroponic system.

\begin{tabular}{|c|c|c|c|c|}
\hline Nutrient & Treatments & Leaves & StemS & RootS \\
\hline \multirow[t]{3}{*}{$\mathrm{N}$} & Complete & 3.34 & 2.88 & 2.45 \\
\hline & $-\mathrm{N}$ & 1.77 & $2.00 *$ & 2.57 \\
\hline & CV (\%) & 25.06 & 14.31 & 27.61 \\
\hline \multirow[t]{3}{*}{$\mathrm{P}$} & Complete & 0.37 & 0.44 & 0.63 \\
\hline & $-\mathrm{P}$ & $0.22 *$ & $0.21 *$ & $0.34 *$ \\
\hline & CV (\%) & 12.34 & 8.27 & 21.74 \\
\hline \multirow[t]{3}{*}{ K } & Complete & 2.07 & 2.22 & 1.87 \\
\hline & $-\mathrm{K}$ & $1.57^{*}$ & $1.62 *$ & $1.59 *$ \\
\hline & CV (\%) & 5.66 & 12.73 & 6.41 \\
\hline \multirow[t]{3}{*}{$\mathrm{Ca}$} & Complete & 2.13 & 0.84 & 0.43 \\
\hline & $-\mathrm{Ca}$ & $1.06^{*}$ & $0.11^{*}$ & $0.02 *$ \\
\hline & CV (\%) & 11.47 & 39.23 & 20.51 \\
\hline \multirow[t]{3}{*}{$\mathrm{Mg}$} & Complete & 0.54 & 0.38 & 0.69 \\
\hline & $-\mathrm{Mg}$ & $0.17^{*}$ & $0.21 *$ & 0.48 \\
\hline & CV (\%) & 8.56 & 21.09 & 30.50 \\
\hline \multirow[t]{3}{*}{ S } & Complete & 0.55 & 0.12 & 0.37 \\
\hline & $-\mathrm{S}$ & $0.10^{*}$ & $0.05^{*}$ & $0.10 *$ \\
\hline & CV (\%) & 19.68 & 17.35 & 17.04 \\
\hline \multirow[t]{3}{*}{ B } & Complete & 41.89 & 16.64 & 60.00 \\
\hline & $-B$ & $21.35^{*}$ & 18.76 & $\bullet$ \\
\hline & CV (\%) & 13.76 & 21.13 & \\
\hline \multirow[t]{3}{*}{$\mathrm{Zn}$} & Complete & 5.90 & 11.52 & 35.14 \\
\hline & $-Z n$ & 4.08 & $6.55^{*}$ & 23.17 \\
\hline & CV (\%) & 15.55 & 16.38 & 25.43 \\
\hline \multirow[t]{3}{*}{$\mathrm{Cu}$} & Complete & 4.75 & 4.72 & 1.08 \\
\hline & $-\mathrm{Cu}$ & 5.85 & 6.20 & 1.52 \\
\hline & CV (\%) & 20.86 & 6.03 & 35.54 \\
\hline \multirow[t]{3}{*}{$\mathrm{Fe}$} & Complete & 94.57 & 69.51 & 980.12 \\
\hline & $-\mathrm{Fe}$ & $115.83 *$ & 53.05 & $468.78^{*}$ \\
\hline & CV (\%) & 12.41 & 51.09 & 25.88 \\
\hline
\end{tabular}

Means followed by * in the column differ from the complete treatment by the Dunnett test at 5\% probability. $\downarrow$ Sample not sufficient to carry out the analysis. 
Table 3. Accumulation of macronutrients and micronutrients $\left(\mathrm{mg} \mathrm{planta}^{-1}\right)$ in leaves, stems and roots of cherry tomato under nutritional deficiencies in hydroponic system.

\begin{tabular}{|c|c|c|c|c|}
\hline Nutrient & Treatments & Leaves & Stems & Roots \\
\hline \multirow[t]{3}{*}{$\mathrm{N}$} & Complete & 360.55 & 230.32 & 401.88 \\
\hline & $-\mathrm{N}$ & $71.11^{*}$ & $81.80^{*}$ & $171.45^{*}$ \\
\hline & CV (\%) & 25.22 & 16.00 & 15.17 \\
\hline \multirow[t]{3}{*}{$P$} & Complete & 39.81 & 35.10 & 13.10 \\
\hline & $-\mathrm{P}$ & $16.62 *$ & $9.06^{*}$ & $4.87^{*}$ \\
\hline & CV $(\%)$ & 18.87 & 16.90 & 40.65 \\
\hline \multirow[t]{3}{*}{ K } & Complete & 221.61 & 176.30 & 39.80 \\
\hline & $-K$ & $133.59^{*}$ & $101.88^{*}$ & 33.50 \\
\hline & CV (\%) & 15.42 & 16.50 & 30.30 \\
\hline \multirow[t]{3}{*}{$\mathrm{Ca}$} & Complete & 228.58 & 66.78 & 8.88 \\
\hline & $-\mathrm{Ca}$ & $85.34 *$ & $7.63 *$ & $0.26^{*}$ \\
\hline & CV $(\%)$ & 19.46 & 38.22 & 31.00 \\
\hline \multirow[t]{3}{*}{$\mathrm{Mg}$} & Complete & 58.43 & 30.54 & 14.85 \\
\hline & $-\mathrm{Mg}$ & $9.38^{*}$ & $6.95 *$ & $2.70^{*}$ \\
\hline & CV (\%) & 22.03 & 25.51 & 44.21 \\
\hline \multirow[t]{3}{*}{$S$} & Complete & 59.53 & 9.63 & 7.80 \\
\hline & $-\mathrm{S}$ & $4.94 *$ & $2.01 *$ & $1.15^{*}$ \\
\hline & CV $(\%)$ & 47.37 & 27.97 & 43.40 \\
\hline \multirow[t]{3}{*}{ B } & Complete & 0.45 & 0.13 & 0.13 \\
\hline & $-B$ & $0.04 *$ & $0.01 *$ & 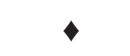 \\
\hline & CV (\%) & 21.21 & 24.22 & \\
\hline \multirow[t]{3}{*}{$\mathrm{Zn}$} & Complete & 0.061 & 0.089 & 0.077 \\
\hline & $-Z n$ & $0.041^{*}$ & $0.054^{*}$ & $0.042 *$ \\
\hline & CV (\%) & 18.63 & 25.12 & 31.77 \\
\hline \multirow[t]{3}{*}{$\mathrm{Cu}$} & Complete & 0.052 & 0.037 & 0.002 \\
\hline & $-\mathrm{Cu}$ & 0.052 & 0.044 & 0.003 \\
\hline & CV (\%) & 31.91 & 27.91 & 39.00 \\
\hline \multirow[t]{3}{*}{$\mathrm{Fe}$} & Complete & 1.004 & 0.562 & 2.230 \\
\hline & $-\mathrm{Fe}$ & $1.327^{*}$ & $0.410^{*}$ & $1.021^{*}$ \\
\hline & CV (\%) & 20.31 & 52.64 & 40.65 \\
\hline
\end{tabular}

Means followed by * in the column differ from the complete treatment by the Dunnett test at $5 \%$ probability

- Sample not sufficient to carry out the analysis.

\section{Phosphorus}

The plants cultivated in nutrient solution deprived of $\mathrm{P}$ at first presented delayed growth and new leaves with purplish coloration (Figure 1C). Later, developed necrotic areas in the leaf margins which progressed towards the central vein. Such symptoms are similar to the reported previously under prolonged P deficiency: dark brown necrotic spots in old leaves, necrotic lesions on leaf margins, death and fall of older leaves (BERGMANN, 1992). 
With the evolution of the P deficiency (Figure 1D), the younger leaves were of smaller length and width. This result is related to the low P supply that reduces the leaf area due to the smaller number of leaves and the limitation of leaf expansion ( $\mathrm{LYNCH}$ et al., 1991; RODRÍGUES et al., 1998). There was also an increase in the leaf angles in relation to the stem, which gives the leaves an appearance of wilting.

Due to the aggravation of the symptoms, $2 \mathrm{~mL}$ of $\mathrm{KH}_{2} \mathrm{PO}_{4} 1 \mathrm{~mol} \mathrm{~L}^{-1}$ solution was added in each vessel of the treatment minus $\mathrm{P}$, so that the plants could reach the end of the experiment. After that, there was a recovery in the plant growth; however, such plants could not perform as well as the plants of the complete treatment. In the final evaluation, the omission of $\mathrm{P}$ did not compromise the number of leaves and inflorescences, but on the other hand, the number of fruits was the most affected trait, with $53 \%$ reduction in relation to the complete treatment (Table 1).

The roots of the plants under $\mathrm{P}$ deficiency presented lower density when compared to the control treatment (Figure 2C). However, Halkesford et al. (2012) states that root growth is less affected by P deficiency than the growth of the aerial part, which promotes decreases in the shoot/root ratio. Such modification is a strategy of the plants that allows better $\mathrm{P}$ acquisition in the radicular environment, due to the adjustment of root growth, producing larger and thinner roots (ZOBEL et al., 2006).

$\mathrm{P}$ deficiency compromises processes such as protein synthesis and photosynthesis, that are carried out with the participation of phosphorus compounds (ALVARENGA, 2013), leading to changes in the development of plants. According to Alvarenga (2013), in tomato, the symptoms of $\mathrm{P}$ deficiency are not very evident. They only appear when the deficiency is already acute. However, the results of the present study reveal that for cherry tomatoes $\mathrm{P}$ deficiency is very limiting, since it was the first deficiency to manifest and, in addition, for the plants to reach the end of the experiment, it was necessary the addition of $\mathrm{P}$ to the nutrient solution.

\section{Potassium}

The plants grown in nutrient solution under $75 \% \mathrm{~K}$ reduction showed no visual symptoms of deficiency, revealing that the amount supplied was enough for their development. According to Mengel and Kirkby (2001), the lack of K does not present immediate visual symptoms, causing primarily reduction of growth and only subsequently leaf marginal chlorosis and necrosis. In the present study, only the NL, RV and DMR of the plants of the treatment minus $\mathrm{K}$ did not differ from the control, and the NI was higher in it, although the number of fruits was significantly lower, indicating the effect of the lack of $\mathrm{K}$ on the flower set.

The other traits were smaller in the treatment minus $\mathrm{K}$ comparatively to the complete solution treatment. These results confirm the importance of $\mathrm{K}$ in fruit formation. Lack of $\mathrm{K}$ results in disturbances in fruit filling. This nutrient acts in the transport of photoassimilates in the phloem and contributes to the accumulation of biomass in the fruit, besides participating in the activation of several enzymes necessary for the synthesis of organic compounds (HALKESFORD et al., 2012; MARENCO; LOPES, 2005).

The concentration of $\mathrm{K}$ in the leaves, stems and roots was lower when compared to plants of the complete solution treatment (Table 1), and the accumulation of this nutrient did not differ between these treatments only in the roots (Table 3). This fact indicates that if the deficiency would be prolonged for few days, the symptoms would manifest. Although not being part any compound, $\mathrm{K}$ is the macronutrient most absorbed by vegetables, and plays important functions in the plant related to maintaining the plant turgor, opening and closing stomata, protein synthesis, photosynthesis and enzymatic activity among others (TAIZ; ZEIGER, 2013). 


\section{Calcium}

The reduction of $50 \% \mathrm{Ca}$ in the nutrient solution did not promote the appearance of visual symptoms of deficiency. Probably, the cultivar studied has low requirement of this nutrient. Ca deficiency in tomato is characterized by blossom end rot, young leaves with necrotic tips and older purple leaves (ALVARENGA, 2013). The roots of Ca deficient plants presented lower volume and brown staining (Figure 2D), however, apparently, the growth did not appear to have been influenced by the reduced amount of this nutrient, although the Ca deficiency is characterized by the reduction in the growth of meristematic tissues (MENGEL; KIRKBY, 2001).

Even though no symptoms of deficiency were observed, and the NL, NI, NFr and DMR did not differ from the control treatment, the other evaluated traits were lower in the minus Ca treatment than in the complete treatment (Table 1). In the treatment deprived of $\mathrm{Ca}$, lower concentrations of $\mathrm{Ca}$ in leaves, stems and roots were observed comparatively to the complete treatment (Table 2), as well as $\mathrm{Ca}$ accumulation in the minus $\mathrm{Ca}$ was lower than in the control treatment in leaves, stems and roots (Table 3). Ca plays several fundamental roles in the plant, such as maintenance of functional integrity of membranes, stabilization of cell wall structures, regulation of transport and ion selectivity, as well as activation of cell wall enzymes (HALKESFORD et al., 2012).

\section{Magnesium}

The plants submitted to the treatment minus $\mathrm{Mg}$ initially presented chlorosis of older leaves, which began at the interveinal portions of the leaf edges and progressed toward the midrib. The region close to the central vein remained green and as the symptoms progressed, necrotic spots evolved in the leaf limbus (Figure 1E). The Mg deficiency affected the growth of the plants, which presented a little dense and deficient root system, evolving to the disintegration of the tissues (Figure 2E).
Only the NL of the minus $\mathrm{Mg}$ treatment did not differ from the control. All the other variables presented reduction compared to the control. The $\mathrm{Mg}$ concentration in the roots did not present significant differences, whereas in the leaves and stem it was reduced (Table 2). In addition, the accumulation of this nutrient in the evaluated tissues was lower than in the control treatment (Table 3) justifying the visual symptoms observed, and the small values of the growth traits evaluated.

The occurrence of chlorosis in older leaves is explained by the fact that $\mathrm{Mg}$ is easily translocated from mature tissues of the plant to the younger ones, and then the first visual symptoms are observed in older leaves (EPSTEIN; BLOOM, 2006). In $S$. quitoense, it was also observed interveinal chlorosis initiated in the foliar edges that reaches the areas near to the central vein, causing early senescence (BOLÍVAR et al., 2009). The absence of Mg affects the size, structure and function of chloroplasts. Since it is constituent of the chlorophyll molecule, its lack always results in chlorosis (HALKESFORD et al., 2012).

\section{Sulfur}

The plants under S deficiency showed reduced growth. The younger leaves were the first to present generalized chlorosis and reduced size in relation to the asymptomatic leaves. The central veins of the leaves presented reddish tonality (Figure 1F). The root system was less dense, but with little growth reduction (Figure 2F). In the absence of $\mathrm{S}$, shoot growth is generally more affected than root growth (BERGMANN, 1992). Cucumber plants in nutrient solution under partial deprivation of $\mathrm{S}$ presented a significant reduction in the dry matter production of roots and root volume (SILVA et al., 2011b). The NL, NI and NFr of the minus S treatment did not differ from the control, whereas the dry matter production and the root volume had lower values than the observed in the control (Table 1). The $\mathrm{S}$ concentration of the leaves, stems and roots of the 
minus $\mathrm{S}$ treatment showed reductions of $92 \%, 78 \%$ and $85 \%$, respectively when compared to the control plants, which resulted in lower accumulation of this nutrient in the analyzed tissues (Tables 2 and 3).

The chlorosis observed in $\mathrm{S}$ deficient plants is a consequence of disorders of protein metabolism at chloroplasts level (BERGMANN, 1992). The $\mathrm{S}$ takes place in essential amino acids and its deficiency interrupts protein synthesis (RAIJ, 1991). Thus, cell division is affected, resulting in smaller plants with lower number of leaves (BURKE et al., 1986). Reductions in shoot dry matter production in cucumber plants were observed in solutions where Fe and S were omitted (SILVA et al., 2011b).

\section{Boron}

The plants submitted to the treatment minus $B$ presented drastic reduction of growth. The leaves were thicker, malformed and with localized necrosis (Figure 1H). It was also observed collapse and premature death of young tissues and apical meristem (Figure 1G).

Due to its relative immobility in tissues, B deficiency results in characteristic growth disorders in meristematic tissues (MENGEL; KIRKBY, 2001). The stem of the plants under B deficiency became thicker and the roots were less dense and smaller (Figure 2G). Absence of B can cause malfunction of vascular cambium tissue that is responsible for the multiplication of the conducting organs cells, causing phloem collapse and, in acute deficiency, the xylem can also be affected (QUAGGIO; PIZA JUNIOR, 2001). Thus, there is a reduction of root growth that does not receive enough quantities of photoassimilates.

The deficiency symptoms observed in B deficient plants are justified by the low values of nutrient concentration and accumulation in the tissues (Table 2 and 3). The production of flowers and fruits was compromised by the non - viability of the meristematic tissues and the low yields of dry matter, especially that of the stem, due to the atrophies of the conductive tissues. Under minus B treatment flowering is severely affected (EPSTEIN; BLOM, 2006). The cherry tomato plants B starved had no onset of inflorescences and, consequently, there were no fruit bunches. The symptoms observed in cherry tomato plants differed from those observed in tomato of the salad group, since for the latter the B was little limiting in the vegetative phase (OLIVEIRA et al., 2009).

\section{Copper}

The plants submitted to the minus $\mathrm{Cu}$ treatment did not present visual symptoms of deficiency. The development of the plants was not affected by the lack of $\mathrm{Cu}$, since only the dry matter production of leaves differed and was smaller than the observed in the complete solution treatment (Table 1). It is possible that the absence of symptoms is due to the low requirement of this element by the cherry tomato plants. In addition, the nutrient concentration in the deficient plants was higher than in the control plants, while the accumulation did not differ between them. It may be possible that the $\mathrm{Cu}$ present as contaminant in the nutrient solution was sufficient to the plant growth, which is common for elements required by plants at very low concentrations (FONTES, 1985). In salad-type tomato, the minus $\mathrm{Cu}$ also did not promote evident symptoms of deficiency (OLIVEIRA et al., 2009).

\section{Zinc}

Plants submitted to Zn deficiency did not present visual symptoms of deficiency in the aerial part, but the roots presented smaller volume in relation to the complete solution treatment (Figure 2H, Table 1). The $\mathrm{Zn}$ concentration of the stems were significantly lower in the minus $\mathrm{Zn}$ treatment. In the leaves and roots, although smaller, these concentrations were not significantly different to that of the control treatment. Regarding the accumulation of $\mathrm{Zn}$ in 
the evaluated organs, all them were reduced in the minus $\mathrm{Zn}$ treatment (Tables 2 and 3).

According to Broadley et al. (2012), Zn deficiency leads to reduction in the activity of the enzyme superoxide dismutase. It favors the increase of oxidative damages and cause a decrease in chlorophyll content. With the intensification of the deficiency, the root system was also affected. In salad-type tomato, the omission of $\mathrm{Zn}$ promoted rickets in the plants and fruit cracking (OLIVEIRA et al., 2009).

Iron

With omission of $\mathrm{Fe}$, interveinal chlorosis was initially observed in the youngest leaves. It evolved from the margins to the center (Figure 2B), and was followed by foliar necrosis, With the intensification of symptoms, the entire leaf area was taken by yellowish coloration. Due to the aggravation of symptoms and the risk of plant premature dying, 1 $\mathrm{mL}$ of Fe-EDTA $35 \mathrm{mmol} \mathrm{L}^{-1}$ solution was added to each replicate of this treatment to allow the plants reaching the end of the experiment. Then, there was recovery of plant growth, and at the end of the experiment only NFr, RV and DMS were lower than the observed in the complete solution treatment (Table 1). However, the roots of the plants submitted to Fe deficiency were less dense, smaller and brownish in appearance (Figure 2I).

The Fe is a constituent or activator of enzymes, has structural function and participates in processes such as photosynthesis, respiration, lignin and suberine synthesis and auxin metabolism (MALAVOLTA, 2006). In the minus Fe treatment, the Fe concentration in the leaves was higher and in the roots was inferior to the observed in the control treatment (Table 2). However, its accumulation in the minus Fe treatment was higher in the leaves and lower in the stems and roots comparatively to the control (Table 3 ). In salad-type tomato, the minus Fe was the one that most affected the development of the plants (OLIVEIRA et al., 2009).

\section{Conclusions}

Based on the observation of the visual symptoms of deficiency, lack of $\mathrm{P}, \mathrm{B}$ and Fe promote the greatest growth restrictions of cherry tomato plants.

The lack of $\mathrm{N}, \mathrm{Mg}$ and $\mathrm{B}$ promote striking reduction of dry matter production of cherry tomato plants.

The individual deficiency of nutrients $\mathrm{N}, \mathrm{P}, \mathrm{K}$, $\mathrm{Ca}, \mathrm{Mg}, \mathrm{S}, \mathrm{B}, \mathrm{Cu}, \mathrm{Zn}$ and $\mathrm{Fe}$ in the nutrient solution reduces the nutrient concentration and accumulation in plants, followed by morphological changes, some of them translated into visible symptoms of deficiencies in cherry tomato plants.

\section{Acknowledgments}

The authors thank the Conselho Nacional de Desenvolvimento Científico e Tecnológico (CNPq) for the financial support and Coordenação de Aperfeiçoamento de Pessoal de Nível Superior (CAPES - Finance Code 001) for granting the doctoral scholarship.

\section{References}

ABRAHÃO, C.; VILLAS BÔAS, R. L.; SILVA, V. C.; RAMOS, A. R. P.; CAMPAGNOL, R.; BARDIVIESSO, D. M. Produção de mini-tomate em função de diferentes relações K:Ca:Mg na solução nutritiva. Horticultura Brasileira, Brasilia, v. 29, n. 2, p. 3813-3819, 2011.

ALVARENGA, M. A. R. Tomate: produção em campo, em casa de vegetação e em hidroponia. 2. ed. Lavras: UFLA, 2013. $455 \mathrm{p}$.

BATAGLIA, O. C.; FURLANI, A. M. C.; TEIXEIRA, J. P. F.; FURLANI, P. R.; GALLO, J. R. Métodos de análise química de plantas. Campinas: Instituto Agronômico de Campinas, 1983. 48 p. (Boletim técnico, 78).

BERGMANN, W. Nutritional disorders of plants: development, visual and analytical diagnosis. Jena: Gustav Fischer, New York, 1992. 741 p.

BLANCHAR, R. W.; REHM, G.; CALDWELL, A. C. Sulfur in plant material by digestion with nitric and perchoric acid. Proceeding-Soil Science Society of America, Madison, v. 29, n. 1, p. 71-72, 1965. 
BOLÍVAR, M. E. V.; MEDELLÍN, L. A. C.; TRUJILLO, M. M. P. Efecto de lãs deficiências de algunos nutrientes em plantas de lulo (Solanum quitoense var. quitoense) em etapa de vivero. Revista Facultad de Ciências Básicas, Bogotá, v. 5, n. 1, p. 64-82, 2009.

BRAGA, J. M.; DEFELIPO, B. Determinação espectrofotométrica de fósforo em extratos de solos e plantas. Revista Ceres, Viçosa, MG, v. 21, n. 113, p. 7385, 1974.

BROADLEY, M.; BROWN, P.; CAKMAK, I.; MA, J. F.; RENGEL, Z.; ZHAO, F. Functions of nutrients: micronutrients. In: MARSCHNER, P. Marschner's mineral nutrition of higher plants. 3th. ed. London: Academic Press, 2012. p. 191-248.

BURKE, J. J.; HOLLOWAY, P.; DALLING, M. J. The effect of sulfur deficiency on the organization and photosynthetic capability of the wheat leaves. Journal of Plant Physiology, Jena, v. 125, n. 3-4, p. 371-375, 1986.

CAMBRAIA, J. Aspectos bioquímicos, celulares e fisiológicos dos estresses nutricionais em plantas. In: NOGUEIRA, R. J. M. C.; ARAUJO, E. L.; WILlADINO, L. G.; CAVALCANTE, U. M. T. (Ed.). Estresses ambientais danos e beneficios em plantas. Recife: UFRPE, Imprensa Universitária, 2005. p. 127137.

CARVALHO, J. L.; PAGLIUCA, L. G. Tomate, um mercado que não para de crescer globalmente. Hortifruti Brasil, Piracicaba, v. 6, n. 58, p. 6-14, 2007.

EPSTEIN, E.; BLOMM, A. J. Nutrição mineral de plantas: princípios e perspectivas. 2. ed. Londrina: Planta, 2006. 403 p.

FELTRIN, D. M.; POTT, C. A.; FURLANI, P. R.; CARVALHO, C. R. L. Produtividade e qualidade de frutos de cultivares de tomateiro fertirrigado com cloreto e sulfato de potássio. Revista de Ciências Agroveterinárias, Lages, v. 4, n. 1, p. 17-24, 2005.

FERNANDES, A. A.; MARTINEZ, H. E. P.; FONTES, P. C. R. Produtividade, qualidade dos frutos e estado nutricional do tomateiro tipo longa vida conduzido com um cacho, em cultivo hidropônico, em função das fontes de nutrientes. Horticultura Brasileira, Brasilia, v. 20, n. 4, p. 564-570, 2002.

FONTES, P. C. R. Diagnóstico do estado nutricional das plantas. Viçosa, MG: Ed. UFV, 2001. 122 p.

FONTES, R. L. F. Purificação de soluções nutritivas para indução de deficiência de zinco e cobre, em plantas. 1985. Dissertação (Mestrado em Agronomia) Universidade Federal de Viçosa, Viçosa, MG.
GENUNCIO, G. C.; SILVA, R. A. C.; SÁ, N. M.; ZONTA, E.; ARAÚJO, A. P. Produção de cultivares de tomateiro em hidroponia e fertirrigação sob razões de nitrogênio e potássio. Horticultura Brasileira, Brasilia, v. 28 , n. 4 , p. 446-452, 2010.

GOMES, J. V. S.; DIAS, N. S.; OLIVEIRA, A. M.; BLANCO, F. F.; SOUZA NETO, O. N. Crescimento e produção de tomate cereja em sistema hidropônico com rejeito de dessalinização. Revista Ciência Agronômica, Fortaleza, v. 42, n. 4, p. 850-856, 2011.

HAGHIGHI, M.; PESSARAKLI, M. Influence of silicon and nano-silicon on salinity tolerance of cherry tomatoes (Solanum lycopersicum L.) at early growth stage. Scientia Horticulturae, Amsterdam, v. 161, n. 1, p. 111-117, 2013.

HALKESFORD, M.; HORST, W.; KICHEY, T.; LAMBERS, H.; SCHJOERRING, J.; MOLLER, I. S.; WHITE, P. Functions of macronutrients. In: MARSCHNER, P. Marschner's mineral nutrition of higher plants. 3th.ed. London: Academic Press, 2012. p. 135-190.

KANAI， S.; ADU-GYMFI， J.; LEI， K.; ITO, J.; OHKURA, K.; MOGHAIEB, R. E. A.; EL-SHEMY, H.; MOHAPATRA, R.; MOHAPATRA, P. K.; SANEOKA, H.; FUJITA, K. N-deficiency damps out circadian rhythmic changes of stem diameter dynamics in tomato plant. Plant Science, Shannon, v. 174, n. 2, p. 183-191, 2008.

KHAVARI-NEJAD, R. A.; NAJAFI, F.; TOFIGHI, C. Diverse responses of tomato to $\mathrm{N}$ and $\mathrm{P}$ deficiency, International Journal of Agriculture and Biology, Faisalabad, v. 11, n. 2, p. 209-213, 2009.

LYNCH, J.; LAUCHLI, A.; EPSTEIN, E. Vegetative growth of the common bean in response to phosphorus nutrition. Crop Science, Madison, v. 31, n. 2, p. 380-387, 1991.

MALAVOLTA, E. Manual de nutrição de plantas. São Paulo: Agronômica Ceres, 2006. 638 p.

MALAVOLTA, E.; VITTI, G. C.; OLIVEIRA, S. A. Avaliação do estado nutricional das plantas: princípios e aplicações. 2. ed. Piracicaba: POTAFOS, 1997. 319 p.

MARENCO, R. A.; LOPES, N. F. Fisiologia vegetal: fotossíntese, respiração, relações hídricas e nutrição mineral. Viçosa, MG: Ed. UFV, 2005. 451 p.

MENGEL, K.; KIRKBY, E. A. Principles of plant nutrition. 5th ed. Dordrecht/Boston/London: Kluwer Academic Publishers, London, 2001. 849 p. 
OLIVEIRA, R. H.; LIMA, M. J. S.; PEREIRAJUNIOR, H. A.; REBOUÇAS, T. N. H.; MORAIS, O. M.; GUIMARÃES, B. V. C.; NOLASCO, C. A. Caracterização de sintomas visuais de deficiência de micronutrientes em tomateiro do grupo salada. Semina: Ciências Agrárias, Londrina, v. 30, n. 1, p. 1093-1100, 2009.

QUAGGIO, J. A.; PIZA JUNIOR, C. T. Frutíferas tropicais. In: FERREIRA, M. E.; CRUZ, M. C. P.; RAIJ, B.; ABREU, C. A. (Ed.). Micronutrientes e elementos tóxicos na agricultura. Jaboticabal: CNPq/FAPESP/ POTAFOS, 2001. p. 459-492.

RAIJ, B. V. Fertilidade do solo e adubação. Piracicaba: Ceres/Potafos, 1991. 343 p.

ROCHA, M. Q. Crescimento, fenologia e rendimento do tomateiro cereja em cultivo hidropônico. 2009. Dissertação (Mestrado em Sistemas de Produção Agrícola Familiar) - Universidade Federal de Pelotas, Pelotas.

RODRÍGUES, D.; KELTJENS, W. G.; GOUDRIAAN, J. Plant leaf area expansion and assimilate production in wheat (Triticum aestivum L.) growth under low phosphorus conditions. Plant Soil, The Hague, v. 200, n. 2, p. 227-240, 1998.

RODRIGUES, M. B.; DORNELLES, A. L. C.; SILVA, V. O. M. Z.; PESSOA, C. A.; SERRALHA, B. C. S.; SILVA, D. A. G.; PEREIRA, M. B. Caracterização morfológica de 25 cultivares de tomateiro tipo cereja caracteres da planta. Horticultura Brasileira, Vitória da Conquista, v. 26, p. 4461-4467, 2008.

SÁNCHEZ-RODRÍGUEZ, E.; LEYVA, R.; CONSTÁNAGUILAR, C.; ROMERO, L.; RUIZ, J. M. Grafting under water stress in tomato cherry: improving the fruit yield and quality. Annals of Applied Biology, Shropshire, v. 161, n. 1, p. 302-312, 2012.

SÁNCHEZ-RODRÍGUEZ, E.; LEYVA, R.; CONSTÁNAGUILAR, C.; ROMERO, L.; RUIZ, J. M. How does grafting affect the ionome of cherry tomato plants under water stress? Soil Science and Plant Nutrition, Temuco, v. 60 , n. 2, p. 145-155, 2014.

SÁNCHEZ-RODRÍGUEZ, E.; MORENO, D. A.; FERRERES, F.; RUBIO-WILHELMI, M. D. M.; RUIZ, J. M. Differential responses of five cherry tomato varieties to water stress: changes on phenolic metabolites and related enzymes. Phytochemistry, London, v. 72, n. 8, p. 723-729, 2011.

SANTOS, A. N.; SILVA, E. F. F.; SILVA, G. F.; BARNABÉ, J. M. C.; ROLIM, M. M.; DANTAS, D. C. Yield of cherry tomatoes as a function of water salinity and irrigation frequency. Revista Brasileira de Engenharia Agrícola e Ambiental, Campina Grande, v. 20, n. 2, p. 107-112, 2016.

SASAKI, J. L. S.; SENO, S. Importância da adubação na qualidade de algumas olerícolas (alho, cebola, couve flor, pimentão e tomate). In: SÁ, E.; BUZZTI, S. Importância da adubação na qualidade dos produtos agrícolas. São Paulo: Ícone, 1994. p. 331-343.

SHABANI, E.; TABATABAEI, S. J.; BOLANDNAZAR, S.; GHASEMI, K. Vegetative growth and nutrient uptake of salinity stressed Cherry tomato in different calcium and potassium level. International Research Journal of Applied and Basic Sciences, Jordan, v. 3, n. 9, p. 18451853, 2012.

SILVA, A. C.; COSTA, C. A.; SAMPAIO, R. A.; MARTINS, E. E. Avaliação de linhagens de tomate cereja tolerantes ao calor sob sistema orgânico de produção. Revista Caatinga, Mossoró, v. 24, n. 3, p. 33-40, 2011 a.

SILVA, G. F.; FONTES, P. C. R.; LIMA, L. P. F.; ARÁUJO, T. O.; SILVA, L. F. Aspectos morfoanatômicos de plantas de pepino (Cucumis sativus L.) sob omissão de nutrientes. Revista Verde, Mossoró, v. 6, n. 2, p. 13-20, $2011 b$.

SILVEIRA, R. L. V.; MOREIRA, A.; TAKASHI, E. N.; SGARBI, F.; BRANCO, E. F. Sintomas de deficiência de macronutrientes e de boro em clones híbridos de Eucalyptus grandis com Eucalyptus urophylla. Cerne, Lavras, v. 8, n. 2, p. 107-116, 2002.

TAIZ, L.; ZEIGER, E. Fisiologia vegetal. 5. ed. Porto Alegre: Artmed, 2013. 820 p.

TRANI, P. E.; PASSOS, F. A.; MELO,A. M. T.; RIBEIRO, I. J. A. Avaliação da produtividade e qualidade comercial de quatro Genótipos de tomate do tipo cereja. In: WORKSHOP TOMATE NA UNICAMP: PESQUISAS E TENDÊNCIAS, 2003, Campinas. Anais... Campinas: FEAGRI/UNICAMP, 2003.

UCHIDA, R. Essential nutrients for plant growth: nutrient functions and deficiency symptoms. In: SILVA, J.A.; UCHIDA, R. (Ed.). Plant Nutrient Management in Hawaii's Soils. College of Tropical Agriculture and Human Resources, University of Hawaii at Manoa, 2000. p. 31-55.

ZOBEL, R. W.; ALlOUSCH, G. A.; BELESKY, D. P. Differential root morphology to no versus high phosphorus, in three hydroponically growth forage chicory cultivars. Environmental and Experimental Botany, Shannon, v. 57, n. 21, p. 201-208, 2006. 